\title{
Review of the Books of Persian Literature in the High School of the Old System and the Second Medium of the New System
}

\section{Revisión de los libros de literatura persa en la escuela secundaria del antiguo sistema y el segundo medio del nuevo sistema}

Majid Soltani
PhD Student of Persian Language and Literature, Islamic Azad University of Neishabour, Iran

Mehdi Norouz

Scientific Member of the Department of Persian Language and Literature, Islamic Azad University of Neishabour, Iran

Akbar Shabani

Scientific Member of the Department of Persian Language and Literature, Islamic Azad University of Neishabour, Iran

\section{Batoul Fakhr Islam}

Scientific Member of the Department of Persian Language and Literature, Islamic Azad University of Neishabour, Iran

Received 01-27-20 Revised 03-03-20 Accepted 05-17-20 On line 06-30-20

*Correspondence

Email: mahdinovrooz@yahoo.com
Cite as:

Soltani, M., Norouz, M., Shabani, A., \& Fakhr Islam, B (2020). Review of the Books of Persian Literature in the High School of the Old System and the Second Medium of the New System. Propósitos y Representaciones, 8(3), e621. doi: http://dx.doi.org/10.20511/pyr2020.v8n3.621 


\section{Summary}

Many educators believe that the intellectual, national, cultural, religious, and literary foundations of each generation are laid in childhood and adolescence. An important part of this is the responsibility of each country's education system. Textbooks are one of the most important tools in this formation. Persian books are a means of narrating human thoughts and imaginations due to their attention to fiction. The present article is a research on the books of Persian literature of the old educational system and Persian of the new educational system. In this study, we intend to examine the books of Persian language and literature of the old system and the Persian books of the second secondary school in the new educational system. Classical literature, contemporary literature, poetic, prose and fusion literature, Iranian and world literature are some of the components that are examined in this research. The authors appear to have focused on the text in older books and to pay more attention to self-examination in new books. This indicates that the new books emphasize greater student engagement.

Keywords: Persian Literature; Old System Persian; New System; Classical Literature; Contemporary Literature; Poetic Literature; Prose Literature; Iranian Literature; World Literature.

\section{Resumen}

Muchos educadores creen que los fundamentos intelectuales, nacionales, culturales, religiosos y literarios de cada generación se establecen en la infancia y la adolescencia. Una parte importante de esto es la responsabilidad del sistema educativo de cada país. Los libros de texto son una de las herramientas más importantes en esta formación. Los libros persas son un medio para narrar pensamientos e imaginaciones humanas debido a su atención a la ficción. El presente artículo es una investigación sobre los libros de literatura persa del antiguo sistema educativo y persa del nuevo sistema educativo. En este estudio, tenemos la intención de examinar los libros de lengua y literatura persa del viejo sistema y los libros persas de la segunda escuela secundaria en el nuevo sistema educativo. La literatura clásica, la literatura contemporánea, la literatura poética, en prosa y de fusión, la literatura iraní y mundial son algunos de los componentes que se examinan en esta investigación. Los autores parecen haberse centrado en el texto de libros antiguos y prestar más atención al autoexamen en libros nuevos. Esto indica que los nuevos libros enfatizan una mayor participación de los estudiantes.

Palabras clave: Literatura persa; Antiguo sistema, persa; Nuevo Sistema; Literatura clásica; Literatura contemporánea; Literatura poética; Literatura en prosa; Literatura iraní; Literatura mundial.

\section{Introduction}

Curricula, as the heart of the education system, are a tool for achieving the goals of education, in other words, one of the important factors that is an integral part of the education system is textbooks.

In our country, educational activities are carried out within the framework of textbooks. All over the country, a textbook is written and distributed among schools for every subject, and teachers focus their activities on the textbook. Examinations and assessments are largely limited to textbook content. Therefore, teaching aids play a very important role in the education system, and textbooks, due to their great importance in achieving educational goals, are the focus of all those involved in education (Principles of Curriculum Planning, Yar Mohammadian: p. 142). 
The compilation of textbooks began with the establishment of new schools. The curriculum of these schools included educational materials that generally did not have a book about them in Iran. Therefore, from the first year of the opening of the Academy of Arts, teachers wrote new books, all of which were published in the printing house of the Academy of Arts (Amir Kabir and Iran, Adamit: pp. 349-372).

Textbooks are one of the main texts studied by children and adolescents. In these texts, several issues are raised. Persian books are one of the richest books in the collection of textbooks in terms of thematic diversity. Literary, religious, and research topics are among the topics considered in Persian books.

So far, various works have been written about textbooks, especially Persian books. However, no research has been written that specifically studies, reviews, and compares Persian books in old and new educational systems.

The following are examples of related research:

Article "Language Challenges (A Critical Look at Persian Language Books in High School)". Written by Tohid Yuzbashi. Growth Journal of Persian Language Teaching No. 71. 1383. The author of this article has tried to show some of the shortcomings of Persian language books in high school with evidence and examples. Issues in the field of compound verb and verb structure recognition, four-part sentences and its types, exceptional sentences, adverb, noun complement, etc. are among these topics. Inserting this article is only a reflection of the author's comments. Some of the above points and corrective comments have been corrected in the publication of 83 Persian language books, both public and human.

"A Study of the Compliance of the Content of Persian Language Textbooks with National Identity in the Academic Year of 2009-2010" by Hajar Kalateh Meymari. Supervisor: Hossein Ghasempour Moghadam. Master Thesis. Payam Noor university. 2011. One of the goals of textbooks is to model, guide, change and correct the attitude and behavior of students in order to develop national identity. To achieve this, it is necessary to know the current situation and plan properly. But the question is, does this matter in school textbooks? And if so, to what extent? The present study examines the level of national identity in Persian language textbooks in the threeyear guidance course.

\section{Educational system}

In today's society, the process of raising children in the family begins, but soon a dedicated organization, the school, officially takes over. The school is a special institution that the community has entrusted with this task, and the curriculum is used by the school to achieve this goal. In other words, the school program is an educational food that the school gives to the students, and in order for this food to be useful in achieving the goals of education, it must be healthy and include all the elements related to the realization of these goals. It is individual and social factors, and changing these factors will lead to program changes. Therefore, the program should benefit from being open to scientific and social innovations (Iranian Children's Literature, Sha'ari Nejad: p. 368).

Textbooks are one of the most important pillars of any educational system and play a decisive role in achieving the goals of the educational system. . Since the education system in the Islamic Republic is centralized and teachers and programs and books are the main axes of 
education and learning, and considering that in many cases textbooks are the only teaching tools available to teachers and students, the teaching process and Learning is based solely on the content of the program and its concepts and values, and since academic evaluations of multiple exams are based on the content of the textbook and the relevant curriculum, the role of the book as the content of the curriculum is considered very important. (Vertical communication analysis in the content of books ..., Fasnqari: p. 3).

After the revolution, the "5-4-3" educational system was established until the beginning of the 1990s. During these years, minor changes were made, such as the elimination of the fourth grade of high school and the inclusion of the pre-university level, but there were no fundamental changes. In the academic year 2012-2012, a new educational system called "3-6-3" was established with an emphasis on structural developments. According to some executives, one of the most important The focus of this educational system is on student participation in academic discussions.

\section{History of teaching Persian literature}

The teaching of Persian literature has been officially and unofficially common among Persian speakers since its inception. With the emergence of masterpieces such as "Ferdowsi's Shahnameh", "Golestan and Bustan Saadi", "Divan Hafez", this training will flourish in formal and informal centers. The teaching of literature in traditional ways has been widely used until the beginning of the present century, and the formal education centers have taught their learners a number of prose works or famous poems of Persian literature. In addition to teaching the masterpieces of Persian literature, which has been to get acquainted with the nature and concepts of Persian literature, other books such as "Nasab Al-Sabian" have been used to teach literary knowledge.

Many books have been written on the subject of Persian language and literature, and in the books of the first twenty years, the names of great figures such as Abdul Azim Gharib, Badiul-Zaman Forouzanfar, and Rashid Yasemi can be found in the group of authors. Each of those books reflects the different tastes of the authors who have shown it by selecting texts. A common feature of all those books is the selection of texts from the works of ancient Iranian poetry and prose. Some of these books were a mixture of various texts, and others were a special text, such as an excerpt from Massoud Sa'd's Rashid Yasemi.

The writing of books on Persian language and literature continued to imitate the past in some cases with some modifications until $1978 \mathrm{AH}$. With the political changes that took place in Iran, there were changes in the structure and content of the book of literature. These developments became more apparent with the outbreak of the Iran-Iraq war. The content changes of the literature books after the Islamic Revolution were more about the issues of revolution and war and specific religious issues. These developments were reflected in the poems and writings of Nasrollah Mardani, Sepideh Kashani, Ayatollah Motahhari, and some other revolutionary poets and writers (Review of the structure and content of high school Persian literature books, Safari Foroushani: pp. 1 and 2).

\section{Persian literature}

The books of Persian literature of the old high school system contain several sections: introduction, textbook, explanations, learn, self-examination and bring that. The final part of the collection of books on Persian language and literature is the dictionary, announcement and 
sources. At the beginning of each chapter, there is an introduction from the books of Persian language and literature of the old system. These introductions are intended to acquaint students with the topics discussed in each chapter. The quality of these preliminaries is not the same, and some have paved the way for discussions in each chapter, and some have been limited to brief explanations.

The main focus of the "Explanations" section in Persian literature books is on the phrases, vocabulary, and terms used in the texts. This is a common practice in the history of textbooks and focuses on direct and indirect instruction. The authors explain the topics by looking at the topics of previous years and knowing the knowledge of the students.

The "Let's Learn" section of Persian literature books, as its name suggests, pursues an educational goal. The literary industry is presented in the same way, away from any educational creativity and innovation.

One of the most important parts of textbooks is self-examination. Smart and accurate questions can lead to purposeful research and study by students. What we encounter in the selftests of Persian literature books are repetitive questions that focus on the text of the lessons. This approach deprives the student of thinking and searching and forces him or her to simply memorize the teachings.

"They have brought that ..." is the title of a part of Persian literature books. In addition to the educational aspect, these sections deal with other aspects of literature that are entertaining.

\section{Persian}

The tenth, eleventh and twelfth Persian books have been compiled in eight chapters. The titles of the chapters are the same in all three pillars. Each chapter includes sections: lesson, research workshop, wisdom treasure, understanding and receiving, poetry reading and psychic reading. The authors have sought to focus on the most important parts of literature in these three pillars, and for students to gain an accurate understanding of literature.

One of the most important differences between this book and the Persian books of the old educational system is the division of educational topics into three domains: linguistic, literary and intellectual. The linguistic realm includes lexical, grammatical, and syntactic levels. The literary realm is devoted to the aesthetic and creative elements of texts and includes phonetic or musical levels, spiritual expression and novelty. The intellectual domain section deals with intellectual characteristics, spirits, tendencies, beliefs, attitudes toward the world, and other aspects of thought.

Most of the contents of the book have been included in the structure of Persian books with the aim of cultivating reading skills, getting acquainted with different texts, cultivating a culture of reading and reading, and creating vitality and mental freshness (Farsi (1), Mohammadian: p. 9).

As mentioned in the introduction to the book, strengthening, understanding and comprehending the text is one of the most prominent educational goals of the lessons in the book.

The approach of the old Persian and Persian literature books of the new system (second secondary) to classical and contemporary literature 
Classical texts have long had an effective presence in textbooks. Various types of literature, including epic, educational, lyrical, etc. are reflected in these texts. Over time, contemporary literature has found its place in textbooks with more rigorous choices. Below the books of Persian literature of the old system and Persian of the new system (second secondary) in different bases were studied and the amount of use of classical and contemporary texts in each of these books was extracted.

The third grade high school Persian language book dedicated to the fields of literature, humanities, Islamic sciences, and Islamic studies has paid more attention to classical literature, and the lowest frequency is the second grade Persian high school literature. Contemporary literature has also had the largest presence in the Persian literature textbook of the first grade of high school.

Classical and contemporary literature did not have the same presence in Persian books of the second secondary school. Classical literature had the highest frequency in the tenth grade and contemporary literature had the highest frequency in the twelfth grade. The lowest contemporary text is in the tenth base with 12 texts.

The approach of old Persian and new Persian literature books (second secondary) to order and prose and integrated texts of order and prose

The texts in these books are not out of three types in terms of the format of the texts; Poetry, prose and a combination of poetry and prose. The authors have chosen a balanced style in choosing the format of the texts.

\section{Conclusion}

The educational books of special schools, especially the books of Persian literature and their role in the initial connection with literature, are clear to everyone. Therefore, literature books should be presented uniformly with accurate and correct data so that the last link between students and literature is not.

In this study, we examined the books of Persian literature of the old system and Persian books of the second secondary school in the new educational system. Classical literature, contemporary literature, poetic literature, prose and fusion, Iranian and world literature were among the components examined in this study. The results of the research conducted in this study showed that:

The third grade of Persian literature is dedicated to classical literature, and the lowest frequency of Persian literature is the second grade of high school. Contemporary literature has also had the largest presence in the Persian literature textbook of the first grade of high school.

\section{Classical and contemporary literature in the book}

Middle Persian speakers did not have the same presence. Classical literature had the highest frequency in the tenth grade and contemporary literature had the highest frequency in the twelfth grade. The lowest contemporary text is in the tenth base with 12 texts.

Poetry texts have had the same presence in the books of Persian literature of the old system except for the third grade of high school (general). The amount of prose texts and poetic and prose fusion texts mentioned in the book of exclusive Persian literature in the fields of 
literature and humanities and Islamic sciences and education of the third grade of high school is more than other bases.

The 11th grade Persian book has more textual diversity. This book contains the highest poetic and fusion texts of poetry and prose. The texts of the tenth verse are more basic than the other bases.

The authors of textbooks in the old and new educational systems have focused on Iranian literature. In addition, the texts included in the World Literature section, despite their literary value, are monophonic and similar texts. Also, many texts have become shorter and more incomplete.

Educational administrators believe that the books in the new education system emphasize more student activity and participation. However, the study of these books showed that this difference did not go beyond the lettering section. The authors present the same old sections in a new context. In Persian books, the new educational system is still a place for creativity, strengthening the spirit of questioning and empty criticism. Most of the material presented focuses on theoretical topics and simple and repetitive questions and answers.

\section{References}

Amir Kabir and Iran. Adamit, Fereydoun (1328). Third edition. Tehran: Kharazmi Publications. Persian literature (3). Third grade high school. Ahmadi, Ahmad and others (2013). 15th edition. Tehran: Iran Textbook Publishing Company.

Persian literature (3). Dedicated to the field of literature and humanities and Islamic sciences and knowledge. Third grade high school. Ershad Sarabi, Asghar et al. (2013). 15th edition. Tehran: Iran Textbook Publishing Company.

Persian language and literature (general). fourth grade of high school. Parsansab, Mohammad and others (1391). Eighteenth edition. Tehran: Iran Textbook Publishing Company.

Persian literature (1). The first grade of high school. Taki, Massoud and others (2012). Sixteenth edition. Tehran: Iran Textbook Publishing Company.

Persian literature (2). Second grade of high school. Davoodi, Hossein and others (2012). 15th edition. Tehran: Iran Textbook Publishing Company.

Children's literature. Shaari Nejad, Ali Akbar (1368). Tehran: Information.

Investigating the structure and content of high school Persian literature books. Safari Foroushani, Hekmatullah (1381). Master Thesis. Tehran Teacher Training University.

Vertical communication analysis in the content of third, fourth and fifth grade elementary mathematics textbooks. Fasnaghari, Hossein (1388). Master Thesis. Kashan University.

Investigating the level of compliance of the content of Persian language textbooks with national identity in the academic year 2010-2011. Kalateh Mimri, Hajar (1390). Master Thesis. Payam Noor university.

Persian (1) The tenth grade of the second year of high school. Mohammadian, Mohieddin and others (1396). Tehran: Iran Textbook Publishing Company.

Persian (2) Eleventh grade of high school. Mohammadian, Mohieddin and others (1396). Tehran: Iran Textbook Publishing Company.

Persian (3), the twelfth grade of the second year of high school. Mohammadian, Mohieddin and others (1397). First Edition. Tehran: Iran Textbook Publishing Company.

Principles of textbook planning. Yar Mohammadian, Mohammad Hussein (1377). Tehran: Yadevareh Publications.

Linguistic Challenges (A Critical Look at Persian Language Books in High School). Yuzbashi, Tawhid (1383). Persian Language Education Growth Magazine. No. 71. 